\title{
Impact of water resources management on area under cultivation level and agricultural production efficiency (Case Study: Villages of Zebarkhan district of Neyshabur city)
}

\author{
Impacto da gestão dos recursos hídricos na área sob nível de cultivo e \\ eficiência da produção agrícola (Estudo de Caso: Aldeias do distrito de \\ Zebarkhan, na cidade de Neyshabur)
}

\author{
Ali Kariznovi' \\ Hamid Jafari"
}

\begin{abstract}
The amount of water consumed in the agricultural sector in Iran is higher than the global average and this necessitates more attention to proper water management in this sector. Due to the climatic conditions of Iran, the average rainfall in most areas is lower than global rainfall. That is to say, the water issue is one of Iran's most important concerns or the greatest challenge for the people of this land. Examining the current agricultural situation indicates that despite the increased agricultural production potential due to the lack of a proper management system, optimal utilization of available resources has not become possible and droughts and reduced rainfall and increasing population followed reduce the amount of water consumed in the agricultural sector. The present study investigates the impact of agricultural water resources management on the economic development of rural settlements (Case study: Villages of Zebarkhan district of Neyshabur city). This research is applied in terms of purpose and in terms of descriptive and analytical method and library and field methods have been used for data collection. According to the results of the present study and data analysis regarding the amount of water consumed in the study area, it was observed that the amount of water consumed per hectare for all crops in modern management lands was less than the fields where managed by the traditional way. This suggests that modern science-based scientific management has played a key role in reducing the loss of water resources within the scope of this study, and in contrast, water loss in farms that are managed in traditional ways is so high. Also, regarding the production efficiency in the study area, the results showed that the production efficiency per hectare for all crops was significantly higher than that under traditional management. This rate varied between 25 to $57.1 \%$.
\end{abstract}

Keywords: Water resource management; Production efficiency; Cultivated area; Neyshabur district

'Ph.D. Student, Department of Geography and Urban Planning, Mashhad branch, Islamic Azad University, Mashhad, Iran - kariznovi.ali@yahoo.com

"Associate Professor, Department of Geography and Urban Planning, Mashhad branch, Islamic Azad University, Mashhad, Iran - hamidjafar@yahoo.com 


\section{Resumo}

A quantidade de água consumida no setor agrícola no Irã é superior à média global e isso requer mais atenção ao gerenciamento adequado da água nesse setor. Devido às condições climáticas do Irã, a precipitação média na maioria das áreas é menor que a precipitação global. Ou seja, a questão da água é uma das preocupações mais importantes do Irã ou o maior desafio para o povo desta terra. O exame da situação agrícola atual indica que, apesar do aumento do potencial de produção agrícola devido à falta de um sistema de manejo adequado, a utilização otimizada dos recursos disponíveis não se tornou possível e as secas e as chuvas reduzidas e o aumento da população seguidos reduzem a quantidade de água consumida na agricultura. setor. O presente estudo investiga o impacto da gestão dos recursos hídricos agrícolas no desenvolvimento econômico de assentamentos rurais (estudo de caso: aldeias do distrito de Zebarkhan, na cidade de Neyshabur). Esta pesquisa é aplicada em termos de finalidade e em termos de método descritivo e analítico e os métodos de biblioteca e campo foram utilizados para a coleta de dados. De acordo com os resultados do presente estudo e análise de dados sobre a quantidade de água consumida na área de estudo, observou-se que a quantidade de água consumida por hectare para todas as culturas em terras modernas de manejo era menor do que os campos administrados pelo tradicional caminho. Isso sugere que a gestão científica moderna baseada na ciência desempenhou um papel fundamental na redução da perda de recursos hídricos no escopo deste estudo e, por outro lado, a perda de água nas fazendas gerenciadas de maneira tradicional é muito alta. Além disso, com relação à eficiência da produção na área de estudo, os resultados mostraram que a eficiência da produção por hectare para todas as culturas foi significativamente maior do que a do manejo tradicional. Essa taxa variou entre 25 e $57,1 \%$.

Palavras-chave: Gerenciamento de recursos hídricos; Eficiência na produção; Área cultivada; Distrito Neyshabur 


\section{Introduction}

Water can be the source of many positive and negative developments in the lives of Earth's inhabitants. The imbalance between water supply and demand can cause a crisis. When this imbalance is not resolved by a set of management strategies, serious differences will raise at the local, regional, national, and international levels. The water crisis is a new title in the literature on water management that points to the inadequate status of the world's water for the needs of human society. This term reflects the status of water worldwide used by the United Nations and other international organizations. Historical evidence suggests that humans have long struggled with water supplies, especially in arid and semi-arid regions. Therefore, the water crisis has been with human throughout the history of human civilization. The current water crisis has transformed national, regional and even global scales from the needs of water or the demand for water and its scale from the local to the past. Some of the signs of a water crisis include: inadequate access to safe drinking water for more than 1.1 billion people, over-use of groundwater, overuse and contamination of water resources that could damage biological diversity, Regional conflicts over limited water resources. (MOZAFFARI, 2010: 2). Freshwater is one of the top issues for the Middle East. Studies also show that freshwater resources are an indispensable factor in achieving sustainable regional development. Among the different countries in the world, the Middle East and North Africa will be most prone to water shortages and droughty. Considering the scarce nature of water resources, widespread conflicts of national resources in the countries of the Middle East and North Africa, traditional competition, increasing urbanization, accelerated industrialization, population growth, rising cultural standards, etc., it will not be too late. Get involved in devastating wars. However, the weakness of the national policies of most of the countries of the region in exploiting the water resources of security concerns, historical, political, ethnic and religious conflicts, escalations and economic competition will aggravate the crisis and worsen the situation in the region. (RAHIMI, 2003: 8).

Khorasan Razavi province, with an area of 118.84 square kilometers, is the fourth largest province in the country and has the worst conditions in terms of water abstraction from underground sources. Every year more than 6 billion cubic meters of water is harvested 
from the Khorasan Razavi plains, which is more than it penetrates the earth. $74 \%$ of the province is in arid climates and $26 \%$ in semi-arid climates and the average rainfall in the province in the last 10 years is $209 \mathrm{~mm}$ which is lower than the average rainfall in the country. It is anticipated that in 2040, out of 73 cities of Khorasan Razavi, 71 cities will face water challenges, which 56 of them will face serious challenges (ESMAILI, 2015). Neyshabur, after Mashhad, is the second largest city of Khorasan Razavi province, located on the slopes of Binalood in northeastern Iran and is one of the most important historical, tourism and industrial centers of the region. The city of Neyshabur has a population of over 250,000 according to the results of the 2016 census. Economics (IRAN STATISTICAL CENTER, 2016). Zebarkhan is one of the districts of Neyshabur which is about 25 kilometers from the center of the city. This section is bounded on the north by the Torqabeh section, on the east by the Ahmadabad section of Mashhad, and on the south by the Kadkan section of Torbat-eHeydariyeh and on the west by the central and mid-Nishabour plains. It covers an area of about 1102 square kilometers, which occupies about $9 \%$ of the area of Neyshabur city center. The population of this section is 57606 according to the results of the 2016 census. Locating in the productive plain of Binalood foothills and proximity to Mashhad, the country's second most populous city, and the crossing of the Tehran-Mashhad highways and railways from within this area, has created a privileged geographical location for this area. Zebarkhan area is rich in surface water and groundwater resources due to its location in the Binalood foothills area and one of the most important rivers in this area is Kharv, Darood, Greene, Dizbaad and Kalshour. (NEYSHABUR GOVERNORATE PORTAL, 2018). Considering the water resources crisis in the country, province, city and the study area, it seems that there should be serious revisions to the water crisis at different levels and dimensions.

Given the above, the main purpose of the present study is to evaluate the impact of rural water resources management on their economic development with case study of villages of Zebarkhan district of Neyshabur city, to help planners administrators manage the crisis better and more efficiently. In this regard the question is as follows:

How is the impact of agricultural water management on the economic development of villages of Zebarkhan district of Neyshabur city? According to the purpose of the research as well as the question raised, the research hypotheses are: 
- There is a significant relationship between the management of agricultural water resources and the increase in the area under cultivation in the villages of Zebarkhan district of Neyshabur city.

- There is a significant relationship between the management of agricultural water resources and the increase of production efficiency in the villages of Zebarkhan district of Neyshabur city.

\section{The importance of the subject}

In arid and arid regions such as Iran, water is the most important limiting factor in economic development, and Principal management of its harvest is of particular importance. Iran's agriculture is dependent on groundwater extraction, and over-harvesting of groundwater resources over the last few decades has led to a significant reduction in static levels and management of groundwater resource utilization is of particular importance in maintaining these resources. Many studies have been conducted on groundwater management and crisis using a variety of techniques. Most of these studies have considered economic objectives and determined the optimal cropping pattern. These goals include maximizing profits, minimizing costs, and maximizing employment. Among the issues that need to be added to economic objectives is water resource management (HEJAZI et al., 2017: 1). The agricultural sector has the highest share of water consumption compared to the urban and industrial uses, and despite the use of methods such as drip irrigation, under pressure and etc. this situation continues. In other words, although agriculture's share of water use has declined from about 90 percent in the early twentieth century to about 60 percent today, it is still the largest consumer of water. In view of this, it can be said that agriculture has the highest dependency on water resources and any disruption to the water supply of this sector will have a serious impact on the food security of countries (ASGARI, 2002: 5).

Studies show that if cultivation of aquatic plants (such as sugar beet, tomato, cotton, etc.) and water use methods continue in the traditional way, and Do not use new technologies in irrigation, in the near future, many villages in Zebarkhan district will have 
acute problems caused by water shortage and droughty so that rural life will be seriously threatened and villages that have played an important role in the agricultural production of the province will become importers of foodstuffs to meet their needs and accelerate rural migration to cities, especially to the outskirts of cities. Therefore, it is necessary to carefully study the status of water resources and irrigation methods, and develop appropriate strategies for sustainable rural development with emphasis on optimal water management. Therefore, the present study is done to regarding of this importance.

\section{Research Method}

The method of this research, in terms of purpose is applied and in terms of nature is descriptive and analytical. In this study, two methods of documentary and library (non-field) and referring to the area and interviews with experts of Ministry of Agriculture Jihad, studied villages' municipalities and exploiters (field) were used for data collection.

The dependent variables of the present study are "economic development of rural settlements" and the independent variables are "increasing the area under cultivation" and "increasing production efficiency".

Subsequently, after collecting the information, basic information tables were prepared for each hypothesis. Finally, by performing the necessary calculations and extracting the performance differences in each field, data analysis was performed and the results were extracted. Then, by matching the results with the hypotheses, each hypothesis was tested.

\section{Research Background}

Table 1 summarizes the literature on the subject under study.

Table 1 - Research Background

\begin{tabular}{c|c|c|c|c}
\hline $\begin{array}{c}\text { Author / } \\
\text { Authors }\end{array}$ & $\begin{array}{c}\text { Release } \\
\text { Year }\end{array}$ & $\begin{array}{c}\text { Type of } \\
\text { effect }\end{array}$ & Subject & Result \\
\hline Davari & 2018 & Book & $\begin{array}{c}\text { Reliable groundwater } \\
\text { management }\end{array}$ & $\begin{array}{c}\text { It has addressed how to achieve equilibrium in } \\
\text { the groundwater resources sector and has } \\
\text { emphasized the change of approach in the } \\
\text { structure of groundwater management as its core. }\end{array}$ \\
\hline
\end{tabular}




\begin{tabular}{|c|c|c|c|c|}
\hline $\begin{array}{l}\text { Jangchi } \\
\text { Kashani } \\
\text { et al. }\end{array}$ & 2017 & Book & $\begin{array}{c}\text { Water Resources } \\
\text { Management in Sustainable } \\
\text { Development of Agriculture }\end{array}$ & $\begin{array}{l}\text { Investigation of Resource Management and } \\
\text { Water Productivity Indicators in Agriculture }\end{array}$ \\
\hline Heydari & 2016 & Book & $\begin{array}{l}\text { Demand Management and } \\
\text { Consumption of Agricultural } \\
\text { Water in Iran }\end{array}$ & $\begin{array}{l}\text { Demand management, concepts, definitions } \\
\text { and requirements for demand management are } \\
\text { presented and economic and non-economic tools } \\
\text { related to agricultural water demand management } \\
\text { are presented and analyzed. }\end{array}$ \\
\hline Dehghani & 2016 & Book & $\begin{array}{l}\text { Iranian Agricultural Water } \\
\text { Demand and Consumption } \\
\text { Management }\end{array}$ & $\begin{array}{c}\text { Water software issues, policies, laws and } \\
\text { programs are associated with their analysis and } \\
\text { evaluation }\end{array}$ \\
\hline $\begin{array}{l}\text { Ziyaie } \\
\text { Mehr }\end{array}$ & 2016 & Book & $\begin{array}{l}\text { Sustainable management of } \\
\text { water resources in agriculture }\end{array}$ & $\begin{array}{l}\text { Key messages in setting sustainable water } \\
\text { resources management policies }\end{array}$ \\
\hline $\begin{array}{l}\text { Davari et } \\
\text { al. }\end{array}$ & 2014 & Book & $\begin{array}{l}\text { Fundamentals of Irrigation } \\
\text { and Drainage Management }\end{array}$ & $\begin{array}{l}\text { There is no solution but to reduce yields and } \\
\text { optimum consumption. }\end{array}$ \\
\hline $\begin{array}{l}\text { Agustov } \\
\text { et al. }\end{array}$ & 2013 & Book & $\begin{array}{l}\text { Principles of water law and } \\
\text { management }\end{array}$ & $\begin{array}{c}\text { Identify the common policies, principles and } \\
\text { rules governing the legal management of water } \\
\text { resources }\end{array}$ \\
\hline $\begin{array}{l}\text { Papoli } \\
\text { Yazdi }\end{array}$ & 2011 & Book & $\begin{array}{l}\text { A Look at Iranian Water } \\
\text { Diplomacy }\end{array}$ & $\begin{array}{l}\text { This book seeks to provide a long-term } \\
\text { perspective on cross-border and transboundary } \\
\text { waters and offer the necessary structures and to } \\
\text { negotiate with neighboring countries on the basis } \\
\text { of the water right of cross-border rivers with } \\
\text { sustainable development partnerships. }\end{array}$ \\
\hline $\begin{array}{l}\text { Parvaresh } \\
\text { et al. }\end{array}$ & 2013 & Book & $\begin{array}{l}\text { Design of water supply } \\
\text { networks }\end{array}$ & $\begin{array}{l}\text { Get familiar with the economic considerations } \\
\text { of design, implementation, and economics of } \\
\text { water supply networks, and on the other hand, the } \\
\text { economic considerations of design as well as the } \\
\text { development and reconstruction of water } \\
\text { networks have been addressed. }\end{array}$ \\
\hline $\begin{array}{l}\text { Khaani et } \\
\text { al }\end{array}$ & 2012 & Book & Global water security & $\begin{array}{l}\text { The current and present conditions of the world } \\
\text { are followed by expressive and illustrative } \\
\text { messages in water discussion from various aspects } \\
\text { such as supply, transmission, purification, } \\
\text { distribution, quality, design, consumption, } \\
\text { management, operation and maintenance. In a few } \\
\text { cases, it has addressed the safety and security } \\
\text { position of water resources. }\end{array}$ \\
\hline Heydari & 2010 & Book & Water saving in agriculture & $\begin{array}{l}\text { It is about successful water conservation in } \\
\text { Australia, Brazil, China and India. }\end{array}$ \\
\hline $\begin{array}{l}\text { Taheri et } \\
\text { al. }\end{array}$ & 2011 & Article & $\begin{array}{l}\text { Access to and conservation } \\
\text { of water resources in crisis }\end{array}$ & $\begin{array}{l}\text { Lack of celestial rains and inappropriate } \\
\text { exploitation have caused the crisis and with the } \\
\text { necessary management and precaution we must } \\
\text { prevent further degradation of resources. }\end{array}$ \\
\hline $\begin{array}{l}\text { Kashkouli } \\
\text { et al. }\end{array}$ & 2015 & Article & $\begin{array}{l}\text { Prioritize water crisis } \\
\text { solutions }\end{array}$ & $\begin{array}{l}\text { Proposed reform of pricing systems, price } \\
\text { change, ownership control and per capita } \\
\text { households to address the water crisis. }\end{array}$ \\
\hline Velayati & 2006 & Article & $\begin{array}{l}\text { Survey of Khorasan Water } \\
\text { Crisis }\end{array}$ & $\begin{array}{l}\text { Overgrazing by deep wells has caused a severe } \\
\text { crisis in the lowlands of the province. }\end{array}$ \\
\hline Rahimi & 2003 & Article & $\begin{array}{l}\text { The water, the unknown } \\
\text { global problem }\end{array}$ & $\begin{array}{l}\text { The 21st century will be the century of the } \\
\text { water crisis, and if not thought out, the water crisis } \\
\text { will cause a disaster in the not too distant future. }\end{array}$ \\
\hline
\end{tabular}




\section{Theoretical Basics}

\subsection{Agricultural Water Resources Management}

In the world, water is getting scarce and the demand for sustainable management of that is increasing rapidly. In this context, in most countries to ensure sustainable water use, policymakers try to take action (ALCON et al., 2014: 193-183). Various policies for sustainable water use are being implemented both by supply and demand. On the supply side, using wastewater, desalination of sea water and the use of unusual water, and on the demand side, policies to reduce consumption and use of water-efficient solutions have been considered (LACH et al., 2005: 83). Consideration of farm irrigation management, including surface irrigation methods, which play a major role in meeting the irrigation needs of crops, is essential. Improvement of the performance of surface irrigation methods is of great importance in optimizing the use of water resources in the country and increasing the efficiency of water use in agriculture. Although in many parts of the world more than $28 \%$ of lands are irrigated with surface irrigation methods, these methods have been neglected. The main problem with surface irrigation methods is the low efficiency resulting from the weakness of irrigation management. By modifying surface irrigation systems in various ways such as land leveling, proper irrigation selection, proper design and management of field water, significant increase in irrigation efficiency is possible (ABSALAN et al, 2007: 11-25).

\subsection{Water crisis}

The water crisis is a new term in the literature on water management that refers to the inadequate status of the world's water for the needs of the human community. This term reflects the status of water on a global scale used by the United Nations and other world organizations. Historical evidence suggests that humans have long struggled to supply water, especially in arid and semi-arid regions, so that the water crisis has been associated with it throughout the history of human civilization. Then water needs or demand for water and its scale have become national, regional and global scales in the past (MOZAFFARI, 2009: 3). 


\subsection{Indicators of water crisis determination}

Various estimates have been made to determine the per capita water needs. These estimates range from about 4654 cubic meters. Hence, there is no single universal criterion for estimating the minimum water requirements per capita. (MAHMOUDI AND SARLAK, 2008: 31). Among the indices considered, the following three are the most valid indices that are always invoked to determine the water crisis:

\subsubsection{Falcon Mark Index}

In his study, the Swedish scientist defined the water crisis based on the per capita amount of each country's renewable water resources. Accordingly, countries with per capita annual renewable water resources of more than 1700 cubic meters are among the countries with water stress and countries with per capita renewable water of less than 1000 cubic meters are among the countries with water shortages. Water per capita of less than 500 cubic meters per year puts a tremendous pressure on that country (BABRAN AND HONARBAKHSH, 2007: 11).

\subsubsection{UN index}

The United Nations Commission on Sustainable Development has identified each country's percentage of renewable water resources as an indicator of measuring the water crisis. According to the UN index, when a country's water harvest exceeds $40 \%$ of its total renewable water resources, the country faces a severe water crisis, and if the amount is between 20 and $40 \%$, the crisis is moderate and if the index is between $10 \%$ and $20 \%$. The crisis is at a moderate level, and for values below $10 \%$, the country is at a low level of crisis.

\subsubsection{Indicators of International Institute of Water Management}

The IWMI uses two factors, the percentage of current harvest is in relation to total annual water resources, and the percentage of future harvest is in relation to current water abstraction at the same time. (BABRAN AND HONARBAKHSH, 2007: 11). 
Table 2 - Estimation of Minimum Per capita Water Needs per Year

\begin{tabular}{|c|c|c|c|}
\hline Source & Year & $\begin{array}{l}\text { Estimated } \\
\text { Rate }(\mathrm{m} 3)\end{array}$ & Base Estimate \\
\hline United Nations & 1976 & 99 & $\begin{array}{l}\text { Minimum water consumption for } \\
\text { community health }\end{array}$ \\
\hline $\begin{array}{c}\text { Schroeder and } \\
\text { Tchobanoglous }\end{array}$ & 1985 & 625 & $\begin{array}{l}\text { Household, industrial, public services } \\
\text { and harvest losses }\end{array}$ \\
\hline $\begin{array}{l}\text { Mohammad Taghi } \\
\text { Monzavi }\end{array}$ & 1986 & 450 & $\begin{array}{l}\text { Minimum requirements for } \\
\text { prosperous industrialized countries }\end{array}$ \\
\hline Falcon Mark & 1986 & 1369 & $\begin{array}{l}\text { Minimum requirements for running a } \\
\text { modern society }\end{array}$ \\
\hline Showal & 1992 & 342 & $\begin{array}{l}\text { Non-agricultural and Food } \\
\text { Consumption }\end{array}$ \\
\hline $\begin{array}{l}\text { Ministry of Energy } \\
\text { of Iran }\end{array}$ & 1992 & 250 & $\begin{array}{l}\text { Per capita consumption of Iranian } \\
\text { people }\end{array}$ \\
\hline Glick & 1996 & 50 & $\begin{array}{c}\text { Primary home, medical and health } \\
\text { needs }\end{array}$ \\
\hline \begin{tabular}{lr}
\multicolumn{1}{c}{ World } & Health \\
Organization & and \\
UNICEF & \\
\end{tabular} & 2000 & 20 & $\begin{array}{l}\text { All basic household, medical and } \\
\text { health needs }\end{array}$ \\
\hline $\begin{array}{l}\text { Howard and } \\
\text { Bartram }\end{array}$ & 2003 & 100 & $\begin{array}{l}\text { All basic household, medical and } \\
\text { health needs }\end{array}$ \\
\hline $\begin{array}{l}\text { International } \\
\text { Institute of Water } \\
\text { Management }\end{array}$ & 2003 & 4654 & $\begin{array}{c}\text { Drinking water for a healthy and } \\
\text { vibrant community }\end{array}$ \\
\hline
\end{tabular}

(Source: Mahmoudi and Sarlak, 2008: 35)

\subsubsection{The role of water in food production, agriculture}

The agricultural sector has the highest share of water consumption compared to the urban and industrial uses and despite the use of methods such as drip irrigation, pressurization, etc., this situation persists. In other words, although agriculture's share of water use has declined from about 90 percent in the early twentieth century to about 60 percent today, it is still the largest consumer of water.

Table 3 - Average Water Consumption of Important Agricultural Items Worldwide and Average Water Consumption in Agriculture (cubic meters per hectare)

\begin{tabular}{c|c}
\multicolumn{1}{c|}{ Product type } & $\begin{array}{c}\text { Global } \\
\text { consumption }\end{array}$ \\
\hline Wheat & $4500-6500$ \\
\hline
\end{tabular}




\begin{tabular}{l|c}
\hline Melon, watermelon, cantaloupe & $7000-10500$ \\
\hline Sugar beet & $5500-7500$ \\
\hline Rice & $4500-7000$ \\
\hline Sugar cane & $15000-25000$ \\
\hline Corn & $5000-8000$ \\
\hline
\end{tabular}

Source: population and water Resources, www.undp. Org

Population growth and agricultural development programs have led to increased areas under irrigation. These areas increased from 50 million hectares in 1900 to 100 million hectares in 1950 and to more than 240 million hectares in 1994.

\section{Introducing the study area}

Zebarkhan is one of the six parts of Neyshabur city located on the southern slopes of the Binalood Mountains between 36 degrees and 20 minutes to 35 degrees and 52 minutes north latitude and 58 degrees and 52 minutes to 59 degrees and 18 minutes east longitude. This section is bounded on the north by Torqabeh section of Mashhad, on the east by the Ahmadabad section of Mashhad, on the south by the Torbat-e-Heydariyeh Kadkan section, on the west by central and middle parts of Neyshabur plain. This section covers an area of about 1102 square kilometers in 2016 with three villages of Ardoghash, EshaghAbad and Zebarkhan with a total of 55 villages and 56598 inhabitants with a centrality of Qadamgah city accounting for about $9 \%$ of the total area of Neyshabur city. Locating in the productive plain of Binalood foothills and proximity to Mashhad, the country's second most populous city, and the crossing of the Tehran-Mashhad highways and railways from within this area, has created a privileged geographical and strategic position for this section, which from this point of view can see its development perspective. Lack of awareness of the number of populations and their geographical distribution has failed economic, social and cultural planning. The household dimension refers to the number of households that are both housing and living expenses. A family whose members have a causal or relative kinship with one another is called a family (JAHANFAR, 2004: 25). Table 4 shows the number and distribution of the rural population in Zebarkhan district. 
Table 4 - Population and Household Dimensions in Zebarkhan District of Neyshabur divided by village 2016

\begin{tabular}{l|c|c|c}
\hline Village & $\begin{array}{c}\text { Number of } \\
\text { Population }\end{array}$ & $\begin{array}{c}\text { Number of } \\
\text { Households }\end{array}$ & $\begin{array}{c}\text { Households } \\
\text { Dimension }\end{array}$ \\
\hline Eshaghabad & 11260 & 3445 & 3.26 \\
\hline Ardoghash & 21693 & 7153 & 3.03 \\
\hline Zebarkhan & 23682 & 7714 & 3.07 \\
\hline Zebarkhan District & 56635 & 18312 & 3.09 \\
\hline
\end{tabular}

Source: Sheriffdom of Zebarkhan and Author Calculations

According to Table 4 in 2016, the highest population belonged to Zebarkhan district and the lowest population belonged to Eshaghabad district.

Zebarkhan sector due to its location in the basin of the Binaloud Mountains and temperate mountainous climate, has favorable conditions for agricultural activities and the basis of livelihood and production system in this sector is based more on agricultural activities. Agriculture in Zebarkhan sector is common in both traditional and industrial sectors, with farmer activities mainly involving agriculture and gardening. Major crops such as wheat, barley, fodder corn, tomatoes and rapeseed and garden products also include plums, apricots, peaches, apples, cherries, pistachios and saffron, which saffron as the most expensive agricultural product and spice in the world has a special place among the region's industrial and export products.

\section{Results}

Agriculture is a major source of freshwater consumption in communities, and providing water as a life-sustaining element of the environment, closely linked to environmental culture and consumption. Due to the fact that our country is located in arid and semi-arid region, the optimal management of water resources in the country requires a huge change. Groundwater resources are one of the most important and inexpensive water resources that proper understanding and utilization of them can play an important role in sustainable development of social and economic activities of a region, especially in arid and semi-arid 
regions. Failure to properly identify and exploit these sources will result in irreparable damage such as severe and irreversible groundwater depletion, reduction of wells and marshes, changes in the pattern of groundwater flow such as advancing saline water fronts and interference with saline waters. In this regard, the government should provide farmers with fair and inclusive modern facilities and equipment to assist in the production of agricultural products. Our country is the best opportunity for agricultural production and self-sufficiency of food imports due to the diverse climate in different regions. The lack of technical knowledge of farmers and the lack of use of experts of Ministry of Agriculture Jihad, wasting water in agricultural lands, crop irrigation, traditional cultivation methods, small land use, lack of technology and modern irrigation techniques due to high costs are factors that cause the lack of agricultural water resources management by the villagers. The use of methods and techniques that require the least amount of water to achieve predetermined goals should replace traditional methods of water use in agriculture and even nonagricultural planning. Food security, one of the pillars of any country's independence, can be achieved through the use of new scientific findings and modern technologies, given the country's population. In the present study, common crops between lands under water resources management (modern irrigation methods) and unmanaged land (traditional irrigation methods) and also gardens in terms of amount of water consumed, production cost per hectare and performance per hectare (efficiency) has been investigated through interviews with the experts of Ministry of Agriculture Jihad, beneficiaries and the villages' municipalities and the findings are as follows:

\subsection{The amount of water consumed}

In general, water as the substance of life had a significant impact on the process of human history. Its abundance has underpinned the prosperity of human civilizations so that the decisive role of water resources in the fate of societies cannot be ignored. Since most of the water consumption in the study area (Zebarkhan sector) is agricultural, the research findings show that if the Type of cultivation of water-loving plants (such as sugar beet, tomato, cotton, etc.) and traditional water use methods continue and do not use new technologies in irrigation, in the near future, many villages in Zebarkhan district will have 
severe problems caused by water shortage and droughty, so that rural life will be seriously threatened and will lead to rural migration to the cities. The results of this research are presented in Table 5.

Table 5 - Water Consumption in Managed and Unmanaged Lands in (Hectare) Zebarkhan Sector, 2018

\begin{tabular}{|c|c|c|c|c|}
\hline \multirow{2}{*}{ Row } & \multirow{2}{*}{ Product } & \multicolumn{2}{|c|}{ Amount of water consumed per hectare } & $\begin{array}{c}\text { Percentage } \\
\text { difference }\end{array}$ \\
\cline { 3 - 5 } & Wheat & 6500 & Unmanaged lands & -46.2 \\
\hline 2 & Barley & 6500 & 9500 & -46.2 \\
\hline 3 & Corn & 9500 & 11000 & -15.8 \\
\hline 4 & Gardens & 9000 & 11000 & -22.2 \\
\hline
\end{tabular}

Source: Agricultural Jihad of Zebarkhan Sector, beneficiaries and the villages' municipalities and author calculations

\subsection{Production efficiency (Performance per hectare)}

Performance is one of the important indicators of the production process. Given that our country is facing water scarcity, efflorescence and economic prosperity and rural employment must be prepared through optimal management of agricultural water resources and production and high efficiency of agricultural products. One of the effective measures in this regard is the use of modern irrigation methods that result in a uniform discharge to the crop area and thereby increase production per unit area, while in the traditional irrigation method, not all crop fields are irrigated equally. The results of the present study on the performance per hectare (efficiency) of joint crops between managed and unmanaged land are presented in Table 6.

Table 6 - Production efficiency per hectare in managed and unmanaged lands

\begin{tabular}{c|c|c|c|c}
\hline \multirow{2}{*}{ Row } & \multirow{2}{*}{ Product } & \multicolumn{2}{|c|}{ Production efficiency per hectare } & \multirow{2}{*}{$\begin{array}{c}\text { Percentage } \\
\text { (kg) }\end{array}$} \\
\cline { 3 - 4 } & & $\begin{array}{c}\text { Managed } \\
\text { Lands }\end{array}$ & $\begin{array}{c}\text { Unmanaged } \\
\text { Lands }\end{array}$ & \\
\hline 1 & Wheat & 5000 & 2200 & 56 \\
\hline
\end{tabular}




\begin{tabular}{c|c|c|c|c}
\hline 2 & Barely & 4200 & 1800 & 57.1 \\
\hline 3 & Corn & 70000 & 35000 & 50 \\
\hline 4 & Gardens & 16000 & 12000 & 25 \\
\hline
\end{tabular}

Source: Agricultural Jihad of Zebarkhan Sector, beneficiaries and the villages' municipalities and author calculations

\section{Conclusion}

In the present study, joint crops between lands under water resources management and unmanaged lands and gardens were studied through interviews with experts, beneficiaries and the villages' municipalities, regarding the amount of water consumed, production cost per hectare, and performance per hectare. The findings are as follows:

The results of the studies on water consumption of major crops in the study area indicate that the amount of water consumed per hectare of all crops in lands under water resources management is less than unmanaged lands. This rate varied between 15.8 and 46.2 percent. If we compare this reduction in water use with the current crop area, the increase in the area under cultivation of these crops would be: barely 762.3 hectares, wheat 577.5 hectares, gardens 2666.4 hectares and corn 55.3 hectares. Therefore, according to the results of the research the first hypothesis is confirmed.

Table 8 - Increase in area under cultivation of major crops due to water use in managed and unmanaged lands

\begin{tabular}{|c|c|c|c|c|c|c|}
\hline \multirow{2}{*}{ Row } & \multirow{2}{*}{ Product } & \multicolumn{2}{|c|}{$\begin{array}{c}\text { Amount of water } \\
\text { consumed per hectare }\end{array}$} & \multirow{2}{*}{$\begin{array}{l}\text { Unmanaged } \\
\text { Area under } \\
\text { cultivation }\end{array}$} & \multirow{2}{*}{$\begin{array}{l}\text { Percentage } \\
\text { difference }\end{array}$} & \multirow{2}{*}{$\begin{array}{l}\text { Increasable } \\
\text { in hectare }\end{array}$} \\
\hline & & $\begin{array}{l}\text { Managed } \\
\text { Lands }\end{array}$ & $\begin{array}{l}\text { Unmanaged } \\
\text { Lands }\end{array}$ & & & \\
\hline 1 & $\begin{array}{l}\text { Watery } \\
\text { Wheat }\end{array}$ & $\begin{array}{c}6500 \\
\text { cubic meters }\end{array}$ & $\begin{array}{l}9500 \text { cubic } \\
\text { meters }\end{array}$ & 1250 & -46.2 & 577.5 \\
\hline 2 & $\begin{array}{l}\text { Watery } \\
\text { Barely }\end{array}$ & $\begin{array}{c}6500 \\
\text { cubic meters }\end{array}$ & $\begin{array}{l}9500 \text { cubic } \\
\text { meters }\end{array}$ & 1650 & -46.2 & 762.3 \\
\hline
\end{tabular}




\begin{tabular}{c|c|c|c|c|c|c}
\hline 3 & $\begin{array}{l}\text { Fodder } \\
\text { corn }\end{array}$ & $\begin{array}{c}9500 \\
\text { cubic meters }\end{array}$ & $\begin{array}{c}11000 \text { cubic } \\
\text { meters }\end{array}$ & 350 & -15.8 & 55.3 \\
\hline 4 & Gardens & $\begin{array}{c}9000 \\
\text { cubic meters }\end{array}$ & $\begin{array}{c}11000 \text { cubic } \\
\text { meters }\end{array}$ & 1200 & -22.2 & 266.4 \\
\hline
\end{tabular}

Source: Agricultural Jihad of Zebarkhan Sector, beneficiaries and the villages' municipalities and author calculations

Also, the results of studies on production efficiency in the study area show that the production efficiency per hectare of all crops in managed lands is higher than unmanaged lands. The rate varied between 25 and 57.1 percent. This increase was respectively $57.1 \%$ for watery barley, $56 \%$ for watery wheat, $50 \%$ for fodder corn and $25 \%$ for gardens, thus confirming the second hypothesis.

Table 9. Production Effect per hectare in Managed and Unmanaged Lands of Zebarkhan

District 2018

\begin{tabular}{|c|c|c|c|c|}
\hline \multirow{2}{*}{ Row } & \multirow{2}{*}{ Product } & \multicolumn{2}{|c|}{$\begin{array}{c}\text { Production efficiency per hectare } \\
\text { (kg) }\end{array}$} & $\begin{array}{c}\text { Percentage } \\
\text { difference }\end{array}$ \\
\cline { 3 - 5 } & & $\begin{array}{c}\text { Managed } \\
\text { lands }\end{array}$ & Unmanaged lands & \\
\hline 1 & Watery Wheat & 5000 & 2200 & 56 \\
\hline 2 & Watery Barely & 4200 & 1800 & 57.1 \\
\hline 3 & Fodder corn & 70000 & 35000 & 25 \\
\hline 4 & Gardens & 16000 & 12000 & 20 \\
\hline
\end{tabular}

Source: Agricultural Jihad of Zebarkhan Sector, beneficiaries and the villages' municipalities and author calculations

Regarding the first hypothesis, based on the results of the studies and data analysis on the amount of water consumed in the study area, it is observed that the amount of water consumed per hectare for all crops under modern management is less than lands where 
water resources have been managed in the traditional way. This suggests that modern science-based scientific management has played a key role in reducing water wasting resources within the scope of this study, and in contrast to water loss in farms that are managed in traditional ways. In the author's field studies, it has been clearly identified that traditional water resources management methods in agriculture are one of the major contributors to increasing water use and reducing irrigation efficiency in Zebarkhan farms. Therefore, through the management of water resources, the area under cultivation will increase dramatically. Concerning the second hypothesis, the results of the studies on production efficiency in the study area show that the production efficiency per hectare for all crops in the area under management is significantly higher than that of the traditional area under management. This rate varied between 25 and 57.1\%.

\section{Suggestions}

The agricultural lands become small parts due to the division of inheritance and in the near future it becomes uncultivated due to lack of economic advantage, so it is suggested that with the creation of agricultural cooperatives, the land will be unified and mechanized and distributed to farmers.

Using traditional irrigation methods will reduce water loss, lower plant nutrients to the root, lower cultivation area, higher costs and increase weeds.

The use of new machinery and modern equipment require banking facilities that farmers cannot use banking facilities due to lack of land ownership documents and having small parts and not being worthy and major landowners benefit from that and this issue is far from justice and causes destruction of smallholder agriculture and migration to cities.

In traditional farming, the experience has been passed down from generation to generation and needs to be updated and utilized by the experts of Ministry of Agriculture Jihad according to current science.

Implanting traditional plants with high water consumption make agriculture unprofitable and without economic benefits, it requires changing the type of planting, and harvesting. 
Considering the fact that farms are small, they need the cooperation and assistance of farmers to be regional in planting, harvesting and integrated use of agricultural machinery and facilities.

Therefore, the government should support active farmers by establishing active cooperatives, reforming agricultural inputs, purchasing products at affordable prices, and preventing rural migration to the cities through the development and prosperity of agriculture and the economy.

Due to traditional planting, and harvesting methods, agricultural crops inherited from their ancestors are not economically viable and require new techniques every day due to modern technologies.

Using modern methods provided by experts of Ministry of Agriculture Jihad and modifying new planting methods, and harvesting products that require less water should go to the aid of farmers and bring about a fundamental transformation in crop production.

\section{References}

Absalan, S, E. Dehghan, F. Abbasi, N. Heydari, H. Farahani, A. Javadi, H. Siadat, and T. Oweis. Evaluation of the best management practices for improving water productivity in the saline areas of lower Karkheh River Basin (KRB). Proceedings of the International Workshop on Improving Water Productivity and Livelihood Resilience in Karkheh River Basin, Sep., Karaj, Iran. Pp: 11- 25, 2007.

Alcon, F., Tapsuwan, S., Martínez-Paz, J.M., Brouwer, R. \& M.D. Miguel. Forecasting Deficit Irrigation Adoption Using a Mixed Stakeholder Assessment Methodology. Technological Forecasting and Social Change, 83(1):183-193, 2014.

Asgari, Mahmood. Strategic Studies Quarterly, Modern Relationship between Water Resources and National Security, Volume 5, Issue 1, 2002.

Augusto et al. Principles of Water Law and Management, Translated by: Shahr-e Danesh Publications, 2013.

Babran, Sedigheh; Honarbakhsh, Nazli. Water Situation Crisis in Iran and the World, Journal of Sustainable Development and Environmental Studies, No. 1, Tehran, Andishe Bartar-e Pouya, 2007. 
Davari, Kamran, Derakhshani, Hashem. Reliable groundwater management, Mashhad Jahade Daneshgahi Publications, 2018.

Davari, Kamran, Salarian, Mohammad. Fundamentals of Irrigation and Drainage Management, Mashhad Jahad-e Daneshgahi Publications, 2014.

Esmailian, Hossein. Managing Director of Khorasan Razavi Water and Wastewater, ISNA News Agency, 2015.

Hejazi, Sayed Asadollah et al. The Importance of Water Resources Management in Iran with Emphasis on Groundwater, Place of Publication, 7th National Conference on Agriculture and Sustainable Natural Resources, 2017.

Heydari, Nader. Agricultural Water Demand and Consumption Management in Iran, Publications of the National Irrigation and Drainage Committee of Iran, 2016.

Jangchi Kashani, Somayeh et al. Water Resources Management in Sustainable Agricultural Development, Academic Publications, 2017.

Kashkoli, Karim et al. Prioritizing Water Crisis Strategies, Strategic, Social and Cultural Quarterly, 2015.

Khaani, Mohammad Reza, Agha Sayyed Abolghasem, Pouya. Global Water Security, Khaniran Publications, 2012.

Lach, D., Rayner, S. \& H. Ingram. Maintaining the Status Quo: How Institutional Norms and Practices Create Conservative Water Organizations. Texas Law Rev. 83(7): 2027-2053, 2005.

Mahmoudi, Behrouz; Sarlak, Mehdi. Estimation of Factors Affecting Water Supply and Demand in Iran and Iran's Position in the Area in Sustainable Development, Expediency Council, Strategic Research Center, 2008.

Mozaffari, Gholam Ali. Global Water Crisis, Challenges and Solutions with Emphasis on Occupied Palestine, 4th International Congress of Islamic Geographers, 2010.

Papoli Yazdi, Mohammad Hussein. A Look at Iranian Water Diplomacy, Papoli Publications, 2011.

Parvaresh, Atefeh et al. Design of water supply networks, NoAvar publication, 2017.

Rahimi, Hossein, 2003, Water crisis: World Unknown Problem, Peyk-e Noor Quarterly Journal of Humanities of Payam Noor University, 2013.

Taheri, Seyyed Danial, Alizadeh, Kamyab. Access and Conservation of Water Resources in Crisis, Aerospace Research Center Publications, Nahaja Health Department, 2011. 
Velayati, Saadollah. Water crisis study of Khorasan province, Ferdowsi University Publications, 2006.

Ziaie Mehr, Mojtaba. Sustainable Water Resources Management in Agriculture, Sana Gostar Publications, 2016. 